Témoigner Témoigner. Entre histoire et mémoire

Getuigen Revue pluridisciplinaire de la Fondation Auschwitz

$124 \mid 2017$

La musique dans les camps

\title{
Wanneer verschillende visies op het herinnerings- beleid botsen met elkaar
}

La mémoire revisitée? Éditorial

\section{Frédéric Crahay}

Traducteur : Anneleen Spiessens

\section{(2) OpenEdition \\ Journals}

Édition électronique

URL : https://journals.openedition.org/temoigner/5638

DOI : $10.4000 /$ temoigner.5638

ISSN : 2506-6390

Éditeur :

Éditions du Centre d'études et de documentation Mémoire d'Auschwitz, Éditions Kimé

Édition imprimée

Date de publication : 2 avril 2017

Pagination : 4

ISBN : 978-2-930953-00-7

ISSN : 2031-4183

Référence électronique

Frédéric Crahay, «Wanneer verschillende visies op het herinnerings-beleid botsen met elkaar», Témoigner. Entre histoire et mémoire [Online], 124 | 2017, Online op 30 novembre 2021, geraadpleegd op 01 décembre 2021. URL: http://journals.openedition.org/temoigner/5638 ; DOI: https://doi.org/

10.4000/temoigner.5638 
$\rightarrow$ Frédéric Crahay,

hoofd van de redactie Vertaling uit het Frans:

Anneleen Spiessens

\section{Wanneer} verschillende visies op het herinneringsbeleid botsen met elkaar

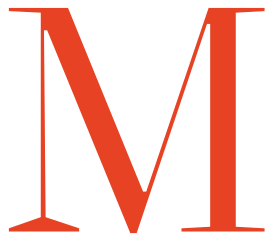

et het Muzeum II Wojny Światowej zou binnenkort een nieuw museum over de Tweede Wereldoorlog haar deuren openen in het Poolse Gdańsk, de stad waar de Duitse pantserkruiser Schleswig-Holstein op 1 september 1939 de oorlog in gang schoot. Het zou het grootste Europese museum worden over de Tweede Wereldoorlog op ons continent, met een parcours van $6800 \mathrm{~m}^{2}$ waaraan een ploeg eminente Poolse en buitenlandse historici acht jaar lang heeft gewerkt. De onenigheid tussen het ministerie van Cultuur (en met name de conservatieve minister Piotr Gliński) en de directie van het museum werpt evenwel een smet op het mooie project. De baan van museumdirecteur en historicus Paweł Machewicz zou zelfs op de tocht staan, terwijl diens mandaat in principe loopt tot in 2019. Machewicz, die het post-1989-tijdperk belichaamt, wenst met de tentoonstelling niet louter het Poolse standpunt weer te geven maar een bredere, Europese visie te omarmen om politieke recuperatie zoveel mogelijk te vermijden. Zijn idee van een museum 'voor Polen en Europeanen' strookt echter niet met het 'nieuwe nationale verhaal voor Polen' dat wordt gepromoot door Gliński's partij Recht en Rechtvaardigheid (PiS).

Moeten we het debacle interpreteren als een terugkeer naar een strikt herinneringsbeleid zoals Polen dat heeft gekend onder het communisme, alleen dit keer aangestuurd door de huidige rechts-nationalistische regering? Alain Frachon, journalist bij de Franse krant Le Monde, luidt de alarmbel in zijn column van 27 januari 2017: 'Generaties jonge Europeanen wordt een pedagogische ervaring ontzegd die nochtans uniek is in de wereld.' Waarschijnlijk zal het museum, waaraan het Belgische bedrijf Tempora bijna acht jaar meewerkte, er slechts in zwaar gewijzigde vorm ooit komen. Het belangenconflict dat vandaag in de schijnwerpers wordt uitgevochten is om verschillende redenen fascinerend. Enerzijds omdat het ministerie van Cultuur het opneemt tegen een reeks gerenommeerde Holocaustspecialisten zoals Timothy Snyder en de Brit Norman Davies. Anderzijds omdat het duidelijk een politieke strijd betreft. Het is immers Donald Tusk, de huidige voorzitter van de Europese raad en zelf een Pool, die het idee voor het museum indertijd lanceerde en groen licht gaf voor de realisatie ervan.

Het ware gevaar dat elke historicus - en meer algemeen, elke wetenschapper - moet onderkennen is dat van een ongeoorloofde vermenging van politieke ideologie en geschiedkundig onderzoek. Begin 2016 liet Polen zich in die zin al opmerken door het ereteken van de Orde van Verdienste af te nemen van historicus Jan Tomasz Gross, omdat diens geschriften 'antipatriottistisch' zouden zijn. Het is natuurlijk zo dat elk museum op de een of andere manier de visie vertolkt van de staatsinstelling die haar financiert. Maar het museum in Gdańsk is nog niet open of de Poolse regering wil al ingrijpen en het parcours heroriënteren. Volgens de media wil ze de geschiedenis zelfs resoluut herschrijven. Sommigen zien het nog somberder in: niet alleen vindt hier een revisie van de geschiedenis plaats, onder onze ogen en in het hart van de Europese Unie wordt een democratisch bestel gaandeweg gemanipuleerd. Als toeschouwers van die krachtmeting wachten wij bang de ontknoping af. We worden er bovendien aan herinnerd hoe belangrijk het wel is, en altijd is geweest, dat wetenschappelijke tijdschriften, net als musea en memorialen, hun intellectuele onafhankelijkheid bewaken. 